\title{
Upaya Meningkatkan Kemampuan Dribble Bola Dalam Permainan Sepakbola Melalui Metode Mengajar Secara Inkuiri Siswa Kelas XI Madrasah Aliyah Madani Alauddin Paopaoka Kabupaten Gowa
}

\author{
Suprianto $^{1}$, Nurwirhanuddin ${ }^{2}$ \\ STKIP Hermon Timika, Papua \\ Email: anjijhi@gmail.com
}

\begin{abstract}
Abstrak. Tujuan penelitian ini adalah mendeskripsikan perencanaan, tindakan observasi, refleksi dan penerapan metode mengajar secara inkuiri dalam upaya meningkatkan kemampuan dribble bola siswa kelas XI Madrasah Aliyah Madani Alauddin Paopao Kabupaten Gowa. Penelitian ini menggunakan penelitian tindakan kelas yang dilaksanakan sebanyak empat kali Pertemuan di Siklus I dan Siklus II dan dirancang melalui empat tahapan yaitu Perencanaan, Pelaksanaan, Observasi, dan Refleksi. Data penelitian ini mencakup tiga rana yaitu psikomotor, afektif, dan kognitif. Data penelitian ini adalah hasil belajar dribble bola dalam permainan sepakbola. Sumber data penelitian ini adalah siswa kelas XI Madrasah Aliyah Madani Alauddin Paopao Kabupaten Gowa, yang berjumlah 34 orang. Pengumpulan data hasil belajar dribble bola pada permainan sepakbola melalui metode mengajar secara inkuiri dianalisis secara Analisis Kualitatif dan Kuantitatif. Hasil penelitian menunjukan bahwa penggunaan metode pembelajaran inkuiri dapat meningkatkan hasil belajar dribble bola siswa kelas XI Madrasah Aliyah Madani Alauddin Paopao Kabupaten Gowa. Adanya peningkatan yang signifikan hasil belajar dribble bola pada permainan sepakbola siswa kelas XI Madrasah Aliyah Madani Alauddin Paopao Kabupaten Gowa, dimana pada siklus (I) presentase kelulusan siswa kelas XI Madrasah Aliyah Madani Alauddin Paopao Kabupaten Gowa, sebesar 61,76\%, ( Tuntas ) dan meningkat pada siklus (II) dengan presentase kelulusan sebesar 94,12\% ( Tuntas ). Kesimpulan penelitian ini adalah dengan penerapan Metode Pembelajaran Inkuiri dapat Meningkatkan Hasil Belajar Dribble Bola Siswa Kelas XI Madrasah Aliyah Madani Alauddin Paopao Kabupaten Gowa.
\end{abstract}

Kata Kunci: Dribble Bola Menggunakan Metode Inkuiri

\section{PENDAHULUAN}

Pembangunan Nasional pada dasarnya merupakan pembangunan manusia seutuhnya dan pembangunan seluruh masyarakat Indonesia dalam segala aspek kehidupan, baik yang bersifat material maupun bersifat spiritual. Oleh karena itu, maka pelaksanaan pembangunan menuntut keterlibatan semua pihak, yaitu pemerintah dan masyarakat baik secara kelembagaan maupun perorangan. Unsur lain yang tak kalah penting dalam pelaksanaan pembangunan adalah keterlibatan semua pihak untuk meningkatkan potensi sumber daya manusia. Karena pada dasarnya menyiapkan sumber daya manusia berkaitan erat dengan meningkatkan pengetahuan, sikap, mental dan kemampuan, sehingga suatu saat dapat berpartisipasi secara aktif dalam pembangunan, baik sebagai pelaku maupun sebagai objek.

Disadari atau tidak, salah satu alternatif peningkatan sumber daya manusia adalah melalui jalur pendidikan, karena kehidupan dan penghidupan yang sesuai dengan nilai-nilai manusia baik secara individu maupun kelompok harus memerlukan bekal kemampuan yang dapat dibentuk melalui jalur pendidikan.

Sejauh ini pendidikan di Indonesia masih dilingkupi banyak permasalahan, salah satunya adalah rendahnya mutu pendidikan di setiap jenjang dan satuan pendidikan terutama pendidikan jasmani, olahraga dan kesehatan yang berjalan di sekolahsekolah. Untuk mengatasi permasalahan tersebut berbagai upaya telah dilakukan, antara lain pengadaan buku dan instrument pengajaran, perbaikan sarana dan prasarana pendidikan jasmani, olahraga dan kesehatan serta peningkatan mutu manejemen sekolah. Tetapi pada kenyataan mutu pendidikan belum menunjukkan peningkatan yang signifikan.

Upaya lain yang dapat dilakukan untuk meningkatkan mutu pendidikan adalah melalui perbaikan dan perubahan dalam proses belajar mengajar atau pembelajaran. Pembelajaran adalah usaha sadar dari seorang guru untuk membelajarkan siswanya dengan sumber belajar dalam rangka mencapai tujuan yang diinginkan. 
Guru merupakan salah satu faktor penentu dalam kegiatan pembelajaran. Guru bukan hanya dituntut untuk mengajar akan tetapi guru juga dituntut melaksanakan tugas profesinya seperti mendorong dan membimbing peserta didik supaya tujuan pendidikan dapat tercapai maksimal.

Agar tujuan pendidikan dapat tercapai guru harus mempunyai kemampuan membuat perencanaan dalam menentukan tujuan pembelajaran, pemilihan materi, strategi, metode, media sumber belajar dan evaluasi yang akan digunakan untuk mempermudah kegiatan pembelajaran. Hal ini sesuai dengan Peraturan Pemerintah Republik Indonesia Nomor 19 Tahun 2005 tentang Standar Nasional Pendidikan (SNP) Pasal 20 yang berbunyi '’Perencanaan proses pembelajaran meliputi silabus dan rencana pelaksanaan pembelajaran yang memuat sekurangkurangnya tujuan pembelajaran, materi ajar, metode pengajaran, sumber belajar, dan penilaian hasil belajar."

Metode pembelajaran seringkali digunakan sebagai cara ataupun solusi bagi para guru ataupun para penyelenggara pendidikan yang lainnya untuk bisa meningkatkan hasil belajar para siswa terhadap materi pembelajaran yang diberikan, di dalam penerapan metode tersebut tentunya membutuhkan upaya bagi guru untuk menerapkannya dengan benar agar harapan materi pembelajaran bisa terserap baik pada siswa dan bisa mendapatkan peningkatan kualitas belajar siswa

Berdasarkan pengamatan awal peneliti di siswa kelas XI Madrasah Aliyah Madani Alauddin Paopao Kabupaten Gowa menunjukkan bahwa pemebelajaran Pendidikan Jasmani, olahraga dan kesehatan yang berjalan di sekolah-sekolah masih kurang, materi pembelajaran yang diberikan kepada siswa masih kurang bisa diaplikasikan dengan baik dan benar, terutama pada materi pembelajaran sepakbola. Terdapat kekurangan yang sangat mendasar dalam tehnik bermain sepakbola, kekurangan yang paling menonjol adalah dalam hal melakukan dribble bola.

Kenyataan yang terjadi sekarang ini, masih banyak para guru pendidikan jasmani kurang memahami metode pembelajaran pendidikan jasmani, olahraga dan kesehatan, hal ini sering dijumpai di lapangan pada saat pembelajaran sedang berlangsung, siswa dibiarkan saja berolahraga sedangkan gurunya hanya bersantai dan tidak mengikuti proses pembelajaran dengan siswanya, ini sudah menjadi hal lumrah dan biasa terjadi di sekolah-sekolah. Kondisi semacam ini sangat memprihatinkan, karena kaidah-kaidah pembelajaran pendidikan jasmani, olahraga dan kesehatan di sekolah-sekolah khususnya di sekolah Madrasah Aliyah Madani Alauddin Paopao tidak dilaksanakan, sehingga tujuan pendidikan jasmani tidak dapat tercapai.

Sepakbola merupakan permainan yang dimainkan oleh dua regu yang masing-masing regu terdiri dari sebelas orang pemain. Ini lasim disebut sebagai kesebelasan. Pada masing-masing regu atau kesebelasan berusaha memasukkan bola sebanyakbanyaknya ke dalam gawang lawan dan mempertahankan gawangnya sendiri agar tidak kemasukan.

Mutu permainan suatu kesebelasan ditentukan oleh penguasaan teknik dasar dalam permainan sepakbola. Seluruh kegiatan dalam permainan dilakukan tanpa bola maupun gerakan dengan bola. Menu wajib dan mendasar dalam latihan sepakbola adalah penguasaan bola secara individu dengan meningkatkan kemampuan dribble. Dribble bola dalam sepakbola memiliki fungsi untuk mempertahankan bola saat berlari melintasi lawan atau maju ke ruang yang terbuka. Dribble dapat menggunakan berbagai bagian kaki (inside, outside, instep, telapak kaki) untuk mengontrol bola sambil terus dribble bola.

Dribble bola juga merupakan salah satu keterampilan dasar yang paling dominan dalam permainan sepakbola untuk usia sekolah menengah dari beberapa keterampilan dasar yang ada, dikarenakan keterampilan dribble bola dengan baik dan benar dapat kita gunakan untuk bertujuan mendekati jarak ke sasaran, melewati lawan dan menghambat permainan dalam permainan sepakbola.

Dribble ialah membawa bola di dalam control sambil berlari. Berarti bola tetap berada dalam penguasaan (bola berada di depan kaki) dan dalam penguasaan untuk dimainkan. Dribble sangat penting untuk dikuasai karena sangat berguna untuk keuntungan tim. Keuntungan dengan dribble adalah bahwa lawan anda tidak akan tahu apa tujuan yang akan anda lakukan selanjutnya.

Pendidikan jasmani, olahraga dan kesehatan merupakan media untuk mendorong pertumbuhan fisik, perkembangan psikis, keterampialan motorik, pengetahuan, penalaran, penghayatan dan nilai-nilai (sikap-mental-emosional-sportivitas-spiritualsosial), serta pembiasaan hidup pola sehat yang bermuara untuk merangsang pertumbuhan dan 
perkembangan kualitas fisik dan psikis yang seimbang.

Tujuan pendidikan jasmani, olahraga dan kesehatan yang utama yaitu ranah kognitif, afektif, dan psikomotor serta fisik selama ini sering terabaikan sehingga tujuan penyerta atau dampak pengiring justru sering diutamakan. Dalam rangka pelaksanaan pendidikan di sekolah yang sangat berperan dan sangat penting adalah seorang guru, sebab gurulah yang secara langsung membina dan mengembangkan kemampuan siswa melalui proses pembelajaran yang dilakukan, upaya pembinaan itulah yang dapat menentukan siswa menjadi cerdas, terampil dan bermoral tinggi seperti yang diharapkan bangsa pada generasi mudanya. Sejumlah kemampuan guru tersebut hendaklah benar-benar diterapkan dalam rangka melaksanakan tugasnya di sekolah, untuk itu semua guru pendidikan jasmani, olahraga dan kesehatan dituntut untuk bisa menguasai semua gerakan dan teknik dasar sepakbola khususnya dribble bola dengan baik dan benar.

Penetapan dan pemilihan jenis keterampilan dalam memilih metode mengajar sangat penting bagi guru mengingat hasil belajar lebih banyak ditentukan oleh kemampuan guru dalam penerapan metode belajar. Salah satu metode yang dapat digunakan dalam proses pembelajaran pendidikan jasmani, olahraga dan kesehatan adalah metode inkuiri. Dengan adanya metode tersebut, siswa dimotivasi berpikir, melibatkan diri dalam kegiatan dan mampu menyelesaikan tugas sendiri.

Pembelajaran dengan metode inkuiri khususnya dribble bola dalam permainan sepakbola di samping bisa mempermudah tehnik dasar, siswa juga memiliki kemampuan untuk menganalisis strategi berpikir mereka, strategi berpikir dapat diajarkan dan ditambahkan kepada siswa, dan inkuiri dapat lebih bermakna dan efektif apabila dilakukan dalam konteks kelompok atau berpasangan. Pembelajaran inkuiri akan menemukan konsep dan prinsip. Konsep dan prinsip itu ditentukan sebagai hasil atau akibat adanya pengalaman belajar yang telah diatur secara seksama oleh pengajar. Namun perlu diperhatikan bahwa pembelajaran metode inkuiri harus disesuaikan dengan tingkat dasar kemampuan siswa.

Berdasarkan pengamatan di lapangan bahwa dalam pembelajaran pendidikan jasmani, olahraga dan kesehatan khususnya pada materi permainan sepakbola terutama dribble bola di sekolah kelas XI Madrasah Aliyah Madani Alauddin Paopao
Kabupaten Gowa masih rendah yang ditinjau dari tingkat penguasaan siswa yaitu belum seperti yang diharapkan dalam proses pembelajaran. Peneliti menemukan dari 34 subjek penelitian diperoleh data sebagai berikut, keterampilan dribble bola dengan melihat faktor kemampuan siswa 9 orang siswa dinyatakan tuntas dengan presentasinya $26,47059 \%$ dan 25 orang siswa dinyatakan tidak tuntas dengan presentasinya $73,52941 \%$. Masalah ini tentu harus segera ditindaklanjuti.

Adapun masalah mendasar menyebabkan aktivitas belajar siswa rendah dipengaruhi oleh banyak faktor dimana faktor tersebut dapat berasal dari guru atau siswa itu sendiri. Penguasaan keterampilan pedagogi yang kurang, keterampilan mengajar yang kurang menyebabkan guru sulit mempraktikkan model-model pembelajaran inovatif sehingga guru beranggapan hanya menggunakan satu model pembelajaran dapat meningkatkan keterampilan dribble bola.

Dari faktor siswa disebabkan tidak adanya motivasi dan minat siswa untuk terus belajar, bola tidak terkontrol pada saat dribble bola, perkenaan kaki dan bola kadang-kadang tidak tepat, pandangan mata saat dribble bola masih terlalu fokus ke arah bola serta siswa hanya menganggap bahwa permainan sepakbola tidak menggunakan teknik dan hanya membutuhkan permainan pada umumnya. Hal inilah yang menyebabkan keterampilan dribble bola siswa masih tergolong rendah, yang seharusnya berada di atas standar Kriteria Ketuntasan Minimal (KKM) sekolah yaitu 70 hal ini disebabkan oleh berbagai faktor yang telah disebutkan satu persatu di atas.

Kenyataan inilah yang terjadi di sekolah Madrasah Aliyah Madani Alauddin Paopao Kabupaten Gowa, dimana guru Pendidikan Jasmani Olahraga dan Kesehatan kurang informasi dan paham tentang model-model pembelajaran, sehingga keterampilan dribble bola siswa rendah.

Adapun permasalahan yang dihadapi siswa pada aspek psikomotorik yang dalam kemampuan dribble bola pada permainan sepakbola, permasalahan yang dialami yaitu pada dribble bola jarak kaki ke bola agak jauh, pandangan mata saat dribble bola masih terlalu fokus ke arah bola, perkenaan kaki dan bola kadang-kadang tidak tepat, dan bola tidak terkontrol pada saat dribble bola.

Berdasarkan hal tersebut, maka peneliti berusaha mencari solusi bagaimana agar tujuan dari pembelajaran kemampuan dribble bola dalam permainan sepakbola dapat tercapai dengan baik. 
Perlu ada usaha untuk memperbaiki dan memecahkan permasalahan itu. Salah satu upaya yaitu menerapkan metode pembelajaran inkuiri.

Metode ini fokus pada siswa pihak yang berperan sebagai subjek pembelajaran adalah siswa. Aktifitas siswa diarahkan untuk menemukan jawaban dari sesuatu yang dipertanyakan oleh guru. Guru hanya berperan sebagai fasilitator yang mengantarkan pada permasalahan melalui pertanyaan. Terutama bagaimana menemukan cara dribble yang benar dalam permainan sepakbola.

Metode pembelajaran inkuiri pada prinsipnya tak hanya mengajarkan siswa untuk memahami dan mendalami materi pembelajaran, tetapi juga melatih kemampuan berpikir siswa dengan baik. Siswa yang mempunyai kemampuan untuk menguasai materi pembelajaran belum tentu bisa mengembangkan proses berpikir benar akan dengan mudah memahami materi pembelajaran. Metode inkuiri ingin menegembangkan kemampuan menguasai materi melalui proses berpikir yang baik.

Berdasarkan observasi yang dilakukan dan dari masalah umum yang dihadapi dalam keterampilan dasar dribble bola dalam permainan sepakbola, maka peneliti tertarik melakukan Penelitian Tindakan Kelas (PTK). Dengan PTK segala sesuatu permasalahan yang terjadi dalam proses belajar mengajar dapat teratasi, membantu membawa perubahan dan meningkatkan proses pembelajaran serta dapat membantu guru dalam memecahkan masalah pembelajaran untuk selanjutnya dicari solusi yang tepat dari berbagai penelitian yang dilakukan para ahli telah mengembangkan berbagai model pengajaran yang dapat digunakan dalam mengajar sesuai dengan permasalahan proses pembelajaran yang dihadapi salah satu alternatif yang digunakan adalah metode pembelajaran inkuiri.

Berdasarkan permasalahan dan harapan yang ingin dicapai, maka penulis mengangkat masalah tersebut dengan judul: "Upaya Meningkatkan Kemampuan Dribble bola Dalam Permainan Sepakbola Melalui Metode Mengajar Secara Inkuiri Siswa Madrasah Aliyah Madani Alauddin Paopao Kabupaten Gowa". TINJAUAN PUSTAKA

\section{a. Pembelajaran Inkuiri}

Dalam pembelajaran ini akan membuat para siswa akan berpikir aktif untuk menemukan jawaban yang dipertanyakan oleh guru. Sementara guru hanya berperan sebagai fasilitator yang mengantarkan pada permasalahan melalui pertanyaan.

Mulyasa, (2011: 108), Inkuiri berasal dari bahasa Inggris "innquiri", yang secara harfiah berarti penyelidikan. Carin dan Sund 1975(dalam Mulyasa 2011:108), mengemukakan bahwa inquiri adalah the process of investigating a problem. Adapun Piaget mengemukakan bahwa metode inkuiri merupakan metode yang mempersiapkan peserta didik pada situasi untuk melakukan eksperimen sendiri secara luas agar melihat apa yang terjadi, ingin melakukan sesuatu, serta menghubungkan penemuan yang satu dengan penemuan yang lain, membandingkann apa yang ditemukanya dengan yang ditemukan peserta didik.

Hartono (2013: 62), inkuiri adalah strategi pembelajaran yang merangsang, mengajarkan, dan mengajak siswa untuk berpikir kritis, analitis, dan sistematis dalam rangka menemukan jawaban secara mandiri dari berbagai permasalahan yang diutarakan.

Berdasarkan beberapa pendapat yang telah dikemukakan di atas, dapat di simpulkan bahwa pembelajaran inkuiri adalah pembelajaaran yang menekankan kepada siswa untuk merangsang, mengaajak dan mengajarkan untuk berpikir kritis, analitis, dan sistematis dalam rangka menemukan jawaban secara mandiri dari berbagai permasalahan yang diutarakan untuk mengolah pesan yang disampaikan oleh guru sehingga memperoleh pengetahuan, keterampilan dan nilai-nilai.

\section{HASIL BELAJAR}

Pendidikan yang baik dan berkualitas tentu akan mengahsilkan output yang baik dan berkualitas pula. Sehinga proses pembelajaran akan menentukan hasil belajar siswa. Dengan melihat hal ini, tentulah hal yang urgen untuk mencari suatu usaha untuk meningkatkan hasil belajar siswa, salah satunya dengan penerapan model-model pembelajaran yang beragam dan inovatif.

Hasil belajar dapat dijelaskan dengan memahami dua kata, yaitu "hasil" dan "belajar". Pengertian hasil (product) menunjuk pada suatu perolehan akibat dilakukannya suatu aktivitas atau proses yang mengakibatkan berubahnya input secara fungsional. Belajar dilakukan untuk mengusahakan adanya perubahan perilaku pada individu yang belajar. Slameto (2013: 2), belajar adalah suatu proses usaha yang dilakukan seseorang untuk memperoleh suatu perubahan tingkah laku yang baru secara keseluruhan, sebagai hasil pengalamannya sendiri dalam interaksi dengan 
lingkungannya. Sanjaya (2008: 170), belajar adalah berbuat; memperoleh pengalaman tertentu sesuai dengan tujuan yang diharapkan.

Skinner (dalam Dimyati dan Mudjiono 2013: 9), belajar adalah suatu perilaku. Pada saat orang belajar, maka responya menjadi lebih baik. Sebaliknya, bila ia tidak belajar maka responya menurun. Dimyati dan Mudjiono (2013: 156), belajar adalah proses melibatkan manusia secara orang per orang sebagai satu kesatuan organisme sehingga terjadi perubahan pada pengetahuan, keterampilan, dan sikap.

Gagne (dalam Dimyati dan Mudjiono 2013: 10), belajar merupakan kegiatan yang kompleks. Hasil belajar berupa kapabilitas. Setelah belajar orang memiliki keterampilan, pengetahuan, sikap, dan nilai.

Berdasarkan beberapa pendapat yang telah dikemukakan di atas, dapat disimpulkan bahwa belajar adalah suatu perilaku manusia secara individu dalam usaha memperoleh pengalaman tertentu dengan tujuan tertentu sehingga terjadi perubahan pada pengetahuan, keterampilan, dan sikap.

\section{KETERAMPILAN DASAR DRIBBLE BOLA}

Pada dasarnya dribble bola adalah menendang terputus-putus atau pelan, dribble bola dalam permainan sepakbola dapat menggunakan berbagai bagian kaki seperti dribble bola menggunakan kaki bagian dalam, bagian luar dan kura-kura kaki. Nugraha (2013: 9), dribble bola adalah olahraga yang paling populer di dunia. Semua kalangan baik tua maupun muda, bahkan tanpa membedakan lakilaki dan perempuan, sangat menggemari olahraga ini. Hal ini sejalan dengan pendapat yang dikemukakan oleh Luxbacher (2011: 47), mengemukakan bahwa dribble bola adalah keterampilan melindungi bola dari lawan yang mencoba merebutnya.

Pada saat dribble bola, pemain tidak boleh terus-menerus melihat bola. Mereka juga harus melihat sekeliling dengan kepala tegak agar dapat mengamati situasi lapangan. Dribble bola bertujuan antara lain untuk mendekati jarak ke sasaran, melewati lawan, dan menghambat permainan. Di bawah ini akan di jelaskan mengenai posisi tubuh saat dribble bola.

1. Dribble bola menggunakan kaki bagian dalam :

Sikap awal :

a Berdiri siap dengan salah satu kaki di depan bola.

b Kaki bagian dalam berhadapan dengan bola
Gerakan :

a. Gerakan mendorong bola atau perkenaan bola perlahan dengan prinsip bola tidak jauh dari kaki.

b. Dribble bola ke depan.

c. Kedua tangan dibuka ke samping.

d. Pandangan mata ke arah depan.

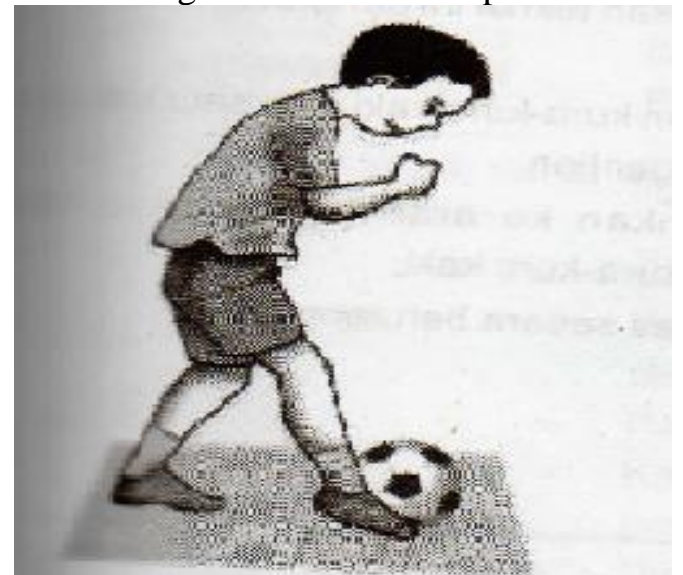

Gambar 1.2Dribble bola dengan kaki bagian dalam Sumber: Mitranto \& Slameto (2010:73)

2. Dribble bola Menggunakan Kaki bagian Luar Sikap awal:

1) Berdiri dengan kedua kaki agak dibuka di dekat bola

2) 2. Kaki yang menyentuh bola agak ke depan

Gerakan:

1) Kaki yang menyentuh bola mendorong perlahan ke depan

2) Gerakan diikuti dengan kontrol bola sehingga bola tidak jauh dari kaki

3) Kedua tangan tetap di samping

4) Pandangan melihat ke arah depan

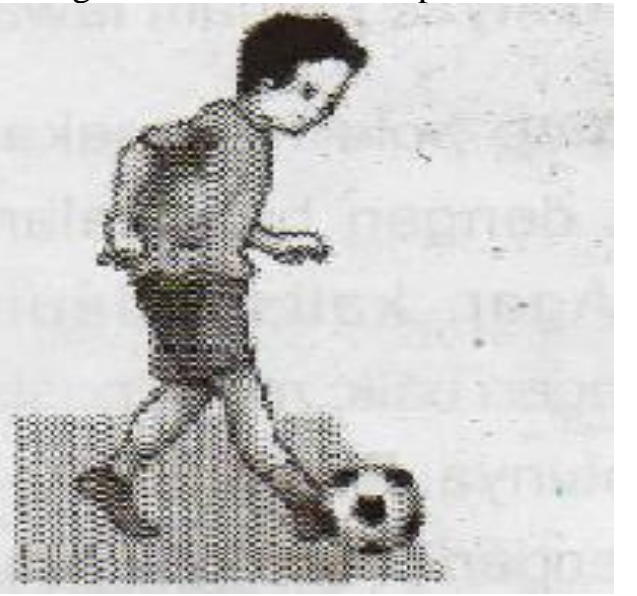

Gambar 1.3Dribble bola dengan kaki bagian luar Sumber:Mitranto \& Slameto (2010:74) 
3. Dribble bola menggunakan kaki bagian tengah (kura-kura)

Sikap awal

1) Berdiri dengan kedua kaki agak dibuka, kiri di depan dan kaki kanan di belakang

2) Bagian kaki ditekuk ke bawah

Gerakan :

1. Perkenaan kaki dengan bola, dilanjutkan dengan gerakan mendorong bola secara perlahan

2. Bola didorong tidak jauh dari kaki

3. Kedua tangan dibuka agak lemas

4. Badan dan pandangan ke arah bola.

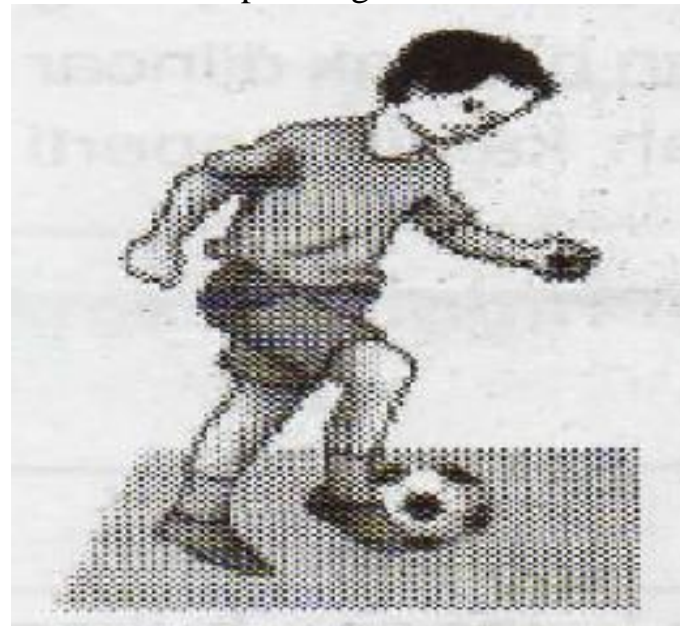

Gambar 1.4 Dribble bola dengan kaki bagian tengah (kura-kura)

Sumber:Mitranto \& Slamet(2010:74)

\section{HASIL PENELITIAN}

Data awal

Siklus I

Tabel 1.3. Data awal hasil belajar Dribble Bola siswa kelas XI Madrasah Aliyah Madani Alauddin Paopao Kabupaten Gowa

\begin{tabular}{|c|c|c|c|c|}
\hline No. & Nilai & Kategori & Frekuensi & Persentase (\%) \\
\hline 1. & $90-100$ & Sangat Baik & 0 & $0 \%$ \\
\hline 2. & $80-89$ & Baik & 0 & $0 \%$ \\
\hline 3. & $70-79$ & Cukup & 9 & $26,47 \%$ \\
\hline 4. & $60-69$ & Kurang & 10 & $29,41 \%$ \\
\hline 5. & $0-59$ & Sangat kurang & 15 & $44,11 \%$ \\
\hline & & Jumlah & 34 & $100 \%$ \\
\hline
\end{tabular}

Tabel di atas diambil dari Direktorat Jenderal Pendidikan Tinggi Departemen Pendidikan Nasional 2009

Berdasarkan tabel di atas dapat dilihat dalam diagram sebagai berikut :

\section{DATA AWAL HASIL BELAJAR DRIBBLE BOLA}

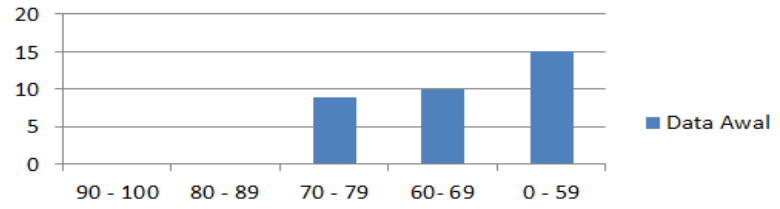

Gambar 1.9. Gambaran frekuensi data awal hasil belajardribble bola

Tabel 1.4. Hasil Belajar Dribble Bola siklus 1 Melalui Metode Mengajar Secara Ikuiri Siswa Kelas XI Madrasah Aliyah Madani Alauddin Paopao Kabupaten Gowa

\begin{tabular}{|c|c|c|c|c|}
\hline No. & Nilai & Kategori & Frekuensi & Persentase (\%) \\
\hline 1. & $90-100$ & Sangat Baik & 0 & $0 \%$ \\
\hline 2. & $80-89$ & Baik & 3 & $8,82 \%$ \\
\hline 3. & $70-79$ & Cukup & 18 & $52,94 \%$ \\
\hline 4. & $60-69$ & Kurang & 12 & $35,29 \%$ \\
\hline 5. & $0-59$ & Sangat kurang & 1 & $2,94 \%$ \\
\hline & & Jumlah & 34 & $100 \%$ \\
\hline
\end{tabular}

Sumber : Hasil Tes Siklus I

Tabel di atas diambil dari Direktorat Jenderal Pendidikan Tinggi Departemen Pendidikan Nasional 2009

Tabel 1.5 : Deskripsi ketuntasan belajar siswa kelas XI Madrasah Aliyah Madani Alauddin Paopao Kabupaten Gowa

\begin{tabular}{|c|c|c|c|}
\hline Kriteria ketuntasan & Kategori & Frekuensi & Presentasi \\
\hline $0-69$ & Tidak Tuntas & 13 & $38,24 \%$ \\
\hline $70-100$ & Tuntas & 21 & $61,76 \%$ \\
\hline & Jumlah & 34 & $100 \%$ \\
\hline
\end{tabular}

Sumber : Analisis data hasil belajar siswa

\section{Siklus II}

Tabel 1.6. Hasil belajar Dribble Bola Siklus 2 melalui Metode Mengajar Secara Ikuiri siswa XI

Madrasah Aliyah Madani Alauddin Paopao Kabupaten Gowa.

\begin{tabular}{|c|c|c|c|c|} 
No. & Nilai & Kategori & Frekuensi & Persentase (\%) \\
\hline 1. & $90-100$ & Sangat Baik & 2 & $5,88 \%$ \\
\hline 2. & $80-89$ & Baik & 15 & $44,11 \%$ \\
\hline 3. & $70-79$ & Cukup & 15 & $44,11 \%$ \\
\hline 4. & $60-69$ & Kurang & 2 & $5,88 \%$ \\
\hline 5. & $0-59$ & Sangat kurang & 0 & $0 \%$ \\
\hline & & Jumlah & 34 & $100 \%$ \\
\hline
\end{tabular}

Sumber : Hasil Tes Siklus II

Dapat dilihat pada diagram batang skor nilai persentase pada siklus II berikut ini: 


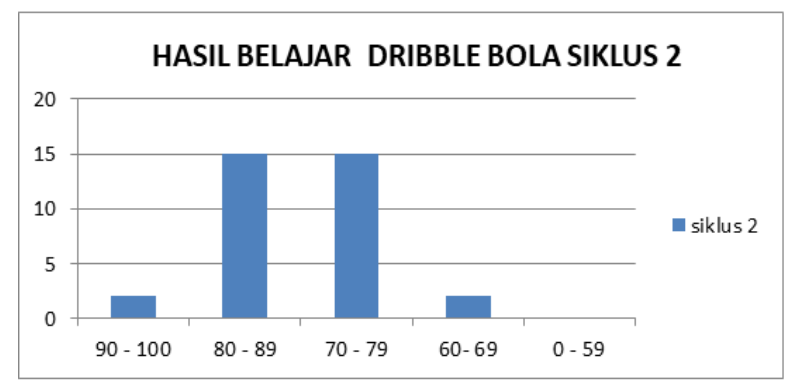

Gambar 2.1. Diagram batang skor nilai persentase pada siklus II

Tabel 1.7. Deskripsi ketuntasan belajar siswa kelas XI Madrasah Aliyah Madani Alauddin Paopao Kabupaten Gowa

\begin{tabular}{|c|c|c|c|}
\hline Kriteria ketuntasan & Kategori & Frekuensi & Presentase(\%) \\
\hline $0-69$ & Tidak Tuntas & 2 & $5,88 \%$ \\
\hline $70-100$ & Tuntas & 32 & $94,12 \%$ \\
\hline & Jumlah & 34 & 100 \\
\hline
\end{tabular}

Sumber : Analisis data hasil belajar siswa Perbandingan Hasil Belajar setiap Siklus

Tabel 1.8 Hasil belajar Dribble bola melalui metode mengajar secara inkuiri kelas XI Madrasah Aliyah Madani Alauddin Paopao Kabupaten Gowa

\begin{tabular}{|c|c|c|c|c|c|c|}
\hline \multirow{2}{*}{ No } & \multirow{2}{*}{ Nilai } & \multirow{2}{*}{ Kategori } & \multicolumn{2}{|c|}{ Siklus I } & \multicolumn{2}{|c|}{ Siklus II } \\
\cline { 4 - 7 } & & & Frekuensi & $\begin{array}{c}\text { Persentase } \\
(\%)\end{array}$ & Frekuensi & $\begin{array}{c}\text { Persentase } \\
(\%)\end{array}$ \\
\hline 1 & $90-100$ & Sangat Baik & 0 & $0 \%$ & 2 & $5,88 \%$ \\
\hline 2 & $80-89$ & Baik & 3 & $8,82 \%$ & 15 & $44,11 \%$ \\
\hline 3 & $70-79$ & Cukup & 18 & $52,94 \%$ & 15 & $44,11 \%$ \\
\hline 4 & $60-69$ & Kurang & 12 & $35,29 \%$ & 2 & $5,88 \%$ \\
\hline 5 & $0-59$ & Sangat kurang & 1 & $2,94 \%$ & 0 & $0 \%$ \\
\hline \multicolumn{3}{|c|}{ Jumlah } & 34 & 100 & 34 & $100 \%$ \\
\hline
\end{tabular}

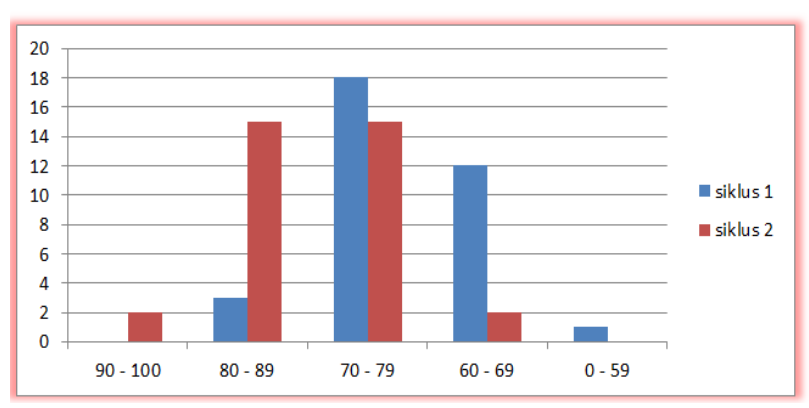

Gambar 2.2. Diagram hasil belajar siswa pada siklus I dan II

Penelitiaan tindakan tentang hasil belajar dribble bola melalui metode mengajar secara inkuiri pada siswa kelas XI Madrasah Aliyah Madani Alauddin Paopao Kabupaten Gowa, dengan tingkat pencapaian nilai rata-rata setiap Siswa 80 dengan standar KKM 70 dan nilai ketuntasan seluruh siswa 94,12\% pada siklus II, sehingga tidak perlu lagi dilanjutkan pada siklus berikutnya.

\section{PEMBAHASAN}

Bentuk kegiatan harian yang diterapkan dalam meningkatkan kemampuan dribble bola pada dasarnya mengarah pada karakteristik gerakan dribble bola dalam bentuk kegiatannya dapat diterapkan sesuai dengan apa yang menjadi pola gerak dasar dari kegiatan dribble bola tersebut :

\section{SIKLUS I}

Siklus I dilaksanakan sebanyak empat kali pertemuan dan untuk tes siklus dilakukan pada pertemuan keempat. Selain itu, setiap pertemuan telah diatur pembelajaran yang akan diajarkan sesuai dengan rencana pelaksanaan pembelajaran agar dalam mengajar ada target bahwa dalam pertemuan tersebut ada beberapa item yang diajarkan

Materi pada pelaksanaan pertemuan pertama yaitu praktik dribble bola kegiatan 1 dribble bola melingkar, kegiatan 2 dribble bola berhadapan dan kegiatan 3 dribble bola mengelilingi lapangan.

Materi pada pelaksanaan pertemuan kedua adalah praktik dribble bola dengan melakukan pengulangan materi yangtelah disampaikan minggu sebelumnya.

Materi pada pelaksanaan pertemuan ketiga adalah praktik dribble bola dengan melakakukan pengulangan materi yang telah disampaikan minggu sebelumnya, dilakukan kegiatan rangkaian dribble bola dengan menggunakan alat bantu sebagai tes siklus pada siklus I.

Adapun bentuk-bentuk kegiatan yang digunakan dalam siklus I dan maksud tujuan pembelajarannya adalah sebagai berikut :

1. Tes harian

Tes harian diberikan pada saat siswa belajar dribble bola di lapangan secara berkelompok. Tes harian ini terdiri dari 3 kegiatan. Tiap-tiap kegiatan berdurasi 20 menit, Tes keterampilan ini terdiri dari:

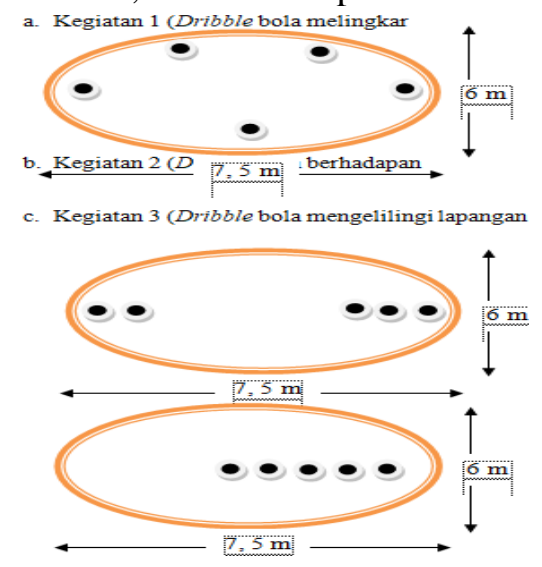


siswa sudah terbiasa melakukan dribble bola yang optimal.

Dari hasil pengamatan yang telah dilakukan dengan menggunakan ketiga kegiatan harian pada siklus I yang nampak cukup optimal hanya bentuk pembelajaran kegiatan berhadapan dribble bola, sedangkan bentuk pembelajaran melingkar, dan mengelilingi lapangan masih belum cukup optimal sehingga pada tahap refkleksi akan dilanjutkan ke siklus kedua dengan catatan kelebihan dan keberhasilan akan ditingkatan pada siklus kedua melalui kegiatan yang lebih menarik dari sebelumnya.

\section{SIKLUS II}

Siklus II dilaksanakan sebanyak empat kali pertemuan dan untuk tes siklus dilakukan pada pertemuan keempat. Selain itu, setiap pertemuan telah diatur pembelajaran yang akan diajarkan sesuai dengan rencana pelaksanaan pembelajaran agar dalam mengajar ada target bahwa dalam pertemuan tersebut ada beberapa item yang diajarkan.

Materi pada pelaksanaan pertemuan pertama, kedua dan ketiga yaitu kegiatan berhadapan dribble bola, dribble bola dengan melingkar, dan dribble bola dengan mengelilingi lapangan.

Materi pada pelaksanaan pertemuan keempat dilakukan kegiatan rangkaian dribble bola dengan menggunakan alat bantu sebagai tes siklus pada siklus II.

Rosdiani (2013:74) mengemukakan prinsip perencanaan pembelajaran yang perlu diperhatikan guru agar terjadinya transfer belajar sebagai berikut:

1) Makin mirip situasi latihan dengan situasi permainan yang sebenarnya makin mungkin terjadinya transfer. Implikasinya, guru dituntut mampu menganalisa aneka ragam situasi yang terdapat pada suatu permainan dan menambahkannya secara bertahap ke dalam situasi berlatih.

2) Makin bervariasi suatu keterampilan dipelajari, makin mungkin terjadinya transfer secara positif terhadap situasi permainan sebenarnya. Implikasinya, belajar skill perlu waktu. Makin banyak waktu dicurahkan untuk transfer, makin mungkin transfer itu terjadi. Kadang-kadang transfer tidak terjadi sebab siswa belum memahami dan belum dapat menerapkan prinsip gerak yang menjadi sumber transfer dengan baik

3) Transfer dapat dilakukan melalui usaha pemberian dorongan oleh gurunya terhadap siswa agar menggunakan informasi dan keterampilan yang sudah dimiliki siswa serta kejelasan aktivitas belajar yang harus dilakukannya. Implikasinya, guru dapat mendorong terjadinya transfer dengan cara memberikan komponen tugas gerak dengan jelas kepada siswa. Cara ini dimaksudkan untuk membuat keterkaitan kognitif secara jelas di antara skill yang dilakukannya, memberikan contoh nyata tentang konsep yang seharusnya diterapkan siswa pada keterampilan lainnya dengan jelas.

\section{KESIMPULAN}

Jadi dapat diperoleh simpulan bahwa pembelajaran melalui metode mengajar secara inkuiri, dapat meningkatkan hasil belajar dribble bola pada siswa kelas XI Madrasah Aliyah Madani Alauddin Paopao Kabupaten Gowa Tahun Ajaran 2016. Dari hasil analisis yang diperoleh peningkatan yang signifikan dari siklus I dan siklus II. hasil belajar dribble bola pada siklus I dalam kategori tuntas adalah $61,76 \%$ jumlah siswa yang tuntas adalah 22 siswa Pada siklus II terjadi peningkatan prosentase hasil belajar dribble bola siswa dalam kategori tuntas adalah sebesar 94,12\% jumlah siswa yang tuntas adalah 32 siswa

\section{DAFTAR PUSTAKA}

Al-Hadiqie, Zidane Muhdhor.2013. Menjadi Pemain Sepak Bola Profesional.___: Kata Pena

Arifin, Zainal. 2009. Evaluasi Pembelajaran. Jakarta: PT Remaja Rosdakarya.

Cipta, Andi Nugraha. 2013. Mahir Sepak Bola. Bandung: Nuansa Cendikia.

Dimyanti dan Mudjiono. 2013. Belajar dan Pembelajaran. Jakarta: Rineka Cipta.

Hartono, Rudi. 2013. Ragam Model Mengajar yang Mudah Diterima SiswaBanguntapan Jogjakarta: DiXIa Press.

Komara, Endang. 2014. Belajar dan Pembelajaran Interaktif. Bandung: Refika Aditama.

Kusumawati, Mia. 2015. Penelitian Pendidikan Penjasorkes. Bandung: Alfabeta.

Kusuma, Wijaya \& Dwitagama, Dedi. Mengenal Penelitian Tindakan Kelas. Jakarta: PT Indeks.

Latif, Muktar. 2014. Filsafat Ilmu. Jakarta: Kencana Pranadamedia Group.

Luxbacher, Joseph A. 2011. Sepak Bola edisi kedua. Jakarta: PT Rajagrafindo Persada. 
Mardalis. 2014. Metode Penelitian Suatu Metode mengajar secara inkuiri Proposal. Jakarta: Bumi Aksara.

Ma'u, Mellius \& Santo J. 2014. Teknik Dasar Bermain Sepak Bola. Yokyakarta: Cakrawala.

Mulyasa. 2011. Menjadi Guru Profesional Menciptakan Pembelajaran dan Menyenangkan. Bandung: Rosda.

Mulyasa. 2013. Praktik Penelitian Tindakan Kelas. Bandung: PT Remaja Rosdakarya.

Nurhasan. 2001. Tes dan Pengukuran dalam Pendidikan Jasmani: Prinsip-prinsip dan Penerapannya.Departemen Pendidikan Nasional.

Pasau, M. Anwar. 2012. Pertumbuhan dan Perkembangan Fisik Pendidikan Jasmani, Olahraga, dan Kesehatan. Makassar: UniXIersitas Negeri Makassar.

Rosdiani, Dini. 2012. Model Pembelajaran Langsung dalam Pendidikan Jasmanidan Kesehatan. Bandung: Alfabeta.

Rosdiani, Dini. 2013. Perencanaan Pembelajaran dalam Pendidikan Jasmani dan Kesehatan. Bandung: Alfabeta.

Rusman. 2012. Model-model Pembelajaran Mengembangkan Profesioalisme Guru. Jakarta: Raja Grafindo Persada.

Sanjaya, Wina. 2006. Strategi Pembelajaran Berorientasi Standar Proses Pendidikan. Bandung: Kencana Prenada Media Group.

Sih Mitranto, Edy dan dkk. 2010. Penjas Orkes. Jakarta: PT Mutiara Permana Bangsa.

Slameto. 2013. Belajar dan Faktor-faktor yang Mempengaruhinya. Jakarta: PT Rineka Cipta.

Suriasumantri, Jujun S. 2009. Filsafat Ilmu. Jakarta: Pustaka Sinar Harapan.

Taniredja, Tukiran dkk. 2012. Penelitian Tindakan Kelas untuk Pengembangan Profesi Guru Praktik, Praktis, dan Mudah. Bandung: Alfabeta.

Wahjoedi. 2001. Landasan Evaluasi Pendidikan Jasmani. Jakarta: PT Raja Grafindo Persada.

Winarno. 2013. Metodologi Penelitian dalam Pendidikan Jasmani. Malang: UniXIersitas Negeri Malang (UM PRESS) 